\title{
Calcium Signaling in Mitral Cell Dendrites of Olfactory Bulbs of Neonatal Rats and Mice During Olfactory Nerve Stimulation and $\beta$-Adrenoceptor Activation
}

\author{
Qi Yuan, Hiroki Mutoh, Franck Debarbieux, and Thomas Knöpfel ${ }^{1}$ \\ Laboratory for Neuronal Circuit Dynamics, Brain Science Institute, RIKEN, Wako-shi, Saitama, 351-0198, Japan
}

\begin{abstract}
Synapses formed by the olfactory nerve (ON) provide the source of excitatory synaptic input onto mitral cells (MC) in the olfactory bulb. These synapses, which relay odor-specific inputs, are confined to the distally tufted single primary dendrites of MCs, the first stage of central olfactory processing. $\beta$-adrenergic modulation of electrical and chemical signaling at these synapses may be involved in early odor preference learning. To investigate this possibility, we combined electrophysiological recordings with calcium imaging in olfactory bulb slices prepared from neonatal rats and mice. Activation of ON-MC synapses induced postsynaptic potentials, which were associated with large postsynaptic calcium transients. Neither electrical nor calcium responses were affected by $\beta$-adrenergic agonists or antagonist. Immunocytochemical analysis of MCs and their tufted dendrites revealed clear immunoreactivity with antibodies against $\alpha 1 \mathrm{~A}$ (Cav2.1, P/Q-type) and $\alpha 1 \mathrm{~B}$ (Cav2.2, N-type), but not against $\alpha 1 \mathrm{C}$ (Cav1.2, L-type) or $\alpha 1 \mathrm{D}$ (Cavl.3, L-type) calcium channel subunits. Moreover, nimodipine, a blocker of L-type calcium channels, had no effect on either electrical or calcium signaling at $\mathrm{ON}-\mathrm{MC}$ synapses. In contrast to previous evidence, we concluded that in neonatal rats and mice (P5-P8), mitral cells do not express significant amounts of L-type calcium channels, the calcium channel type that is often targeted by $\beta$-adrenergic modulation. The absence of $\beta$-adrenergic modulation on either electrical or calcium signaling at ON-MC synapses of neonatal rats and mice excludes the involvement of this mechanism in early odor preference learning.
\end{abstract}

Early odor preference learning is observed in neonatal rats when they form a preference to an odor that is paired with a reinforcing stimulus (Sullivan et al. 1989; Sullivan and Wilson 1994; Wilson and Sullivan 1994). This form of learning depends on noradrenergic neurotransmission in the main olfactory bulb (MOB) that receives noradrenergic input exclusively from the locus coeruleus (Shipley et al. 1985; McLean et al. 1989; McLean and Shipley 1991). Both $\alpha$ - and $\beta$-adrenoceptors are localized in the MOB (Wanaka et al. 1989; Nicholas et al. 1993a,b; Woo and Leon 1995; Day et al. 1997; Winzer-Serhan et al. 1997; Yuan et al. 2003) and might therefore contribute differentially to early odor preference learning. Although work in vitro (Trombley 1992, 1994; Trombley and Shepherd 1992) and in vivo (Jiang et al. 1996) has indicated norepinephrine (NE)-mediated disinhibition via $\alpha$-adrenoceptors, a role of $\alpha$-adrenoceptors in early odor preference learning has only been recently proposed (McLean et al. 2003). On the other hand, activation of $\beta$-adrenoceptors has been shown to promote learning-dependent behavioral and neural changes (Wilson and Sullivan 1994; Coopersmith and Leon 1995). Early odor preference learning in the MOB is blocked by $\beta$-adrenoceptor antagonists; and the effect of reinforcing stimulus required for early odor preference learning can be provided by application of $\beta$-adrenoceptor agonists. On the basis of these findings, it has been proposed that $\beta$-adrenoceptor activation is both necessary and sufficient for early odor preference learning (Sullivan et al. 2000; but see McLean et al. 2003).

In a recent cellular model for early odor preference learning,

'Corresponding author.

E-MAIL tknopfel@brain.riken.go.jp; FAX 81-48-467-9739.

Article and publication are at http://www.learnmem.org/cgi/doi/10.1101/ Im.75204.
Yuan et al. (2003) proposed that $\beta_{1}$-adrenoceptor activation triggers an intracellular cAMP cascade, whereas ON input triggers an influx of $\mathrm{Ca}^{2+}$ in $\mathrm{MC}$ dendrites. The coincident activation of the cAMP cascade and increased $\mathrm{Ca}^{2+}$ levels facilitates $\mathrm{Ca}^{2+} /$ calmodulin phosphorylation of cAMP response element (CRE)binding protein (CREB) and CRE-regulated gene transcription. In this model, the cAMP-UCS (unconditioned stimulus) and $\mathrm{Ca}^{2+}$ CS (conditioned stimulus) pathways are hypothesized to converge at the level of CREB phosphorylation/dephosphorylation. There are several possible scenarios, however, for an interaction of the two pathways at an earlier stage. First, the $\mathrm{Ca}^{2+}$ pathway may enhance the cAMP cascade. This possibility has been excluded because odor input itself did not change the cAMP level. Furthermore, odor plus stroking (tactile stimulation) did not provide an additional increase to the cAMP level compared with stroking alone (Yuan et al. 2003). The second possibility for an interaction of the cAMP and the $\mathrm{Ca}^{2+}$ pathways at an early stage is the direct enhancement of the odor-induced $\mathrm{Ca}^{2+}$ signaling via the $\beta_{1}$-adrenoceptor.

In both the hippocampus and the amygdala, the modulation of $\mathrm{Ca}^{2+}$ signaling by $\beta$-adrenoceptors has been proposed to play a critical role during long-term memory formation (Gray and Johnston 1987; Huang et al. 1993, 1996). The pairing of CS and UCS inputs during fear conditioning leads to $\mathrm{Ca}^{2+}$ entry through both NMDA receptors and L-type $\mathrm{Ca}^{2+}$ channels in lateral amygdala principal neurons (Bauer et al. 2002). Activation of $\beta$-adrenoceptors has been reported to facilitate glutamate release in the amygdala by increasing presynaptic $\mathrm{Ca}^{2+}$ influx (Huang et al. 1993, 1996). In hippocampal pyramidal cells, NE and $\beta$-adrenoceptor agonists increase the activity of postsynaptic L-type calcium channels (Gray and Johnston 1987); the activation of L- 


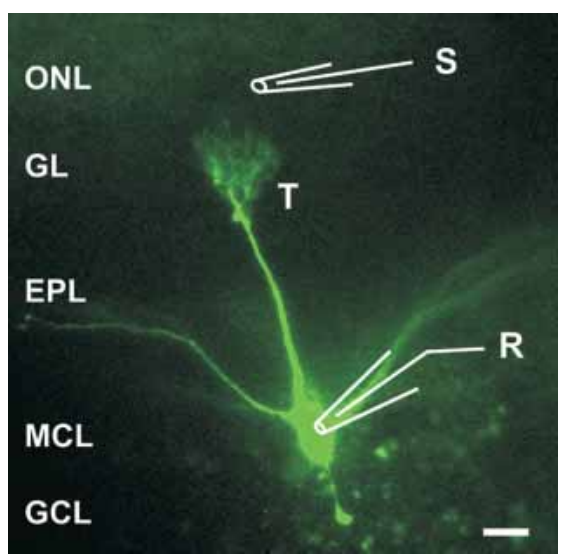

Figure 1 Morphology of a mitral cell (MC) in an olfactory bulb slice of a P6 mouse and positions of electrodes. The MC was filled through the patch-clamp electrode (also recording pipette, R) with $100 \mu \mathrm{M}$ Oregon Green and fluorescence was imaged. Stimulation pipette (S) was placed in the olfactory nerve layer (ONL). (GL) Glomerular layer; (EPL) external plexiform layer; (MCL) mitral cell layer; $(\mathrm{GCL})$ granule cell layer. $(\mathrm{T})$ The tuft of the mitral cell apical dendrite. Scale bar, $50 \mu \mathrm{m}$.

type $\mathrm{Ca}^{2+}$ channels, but not NMDA receptors, leads to sustained nuclear CREB phosphorylation and CREB-driven gene expression (Hardingham et al. 2001).

In the current study, we combined intracellular recordings and $\mathrm{Ca}^{2+}$ imaging with immunocytochemical analysis to test whether $\beta$-adrenoceptor activation also affects $\mathrm{Ca}^{2+}$ signaling in the olfactory bulb as seen in other systems. Our results demonstrate the absence of $\beta$-adrenergic modulation on both electrical synaptic transmission between the $\mathrm{ON}$ and MCs and synaptically induced $\mathrm{Ca}^{2+}$ signals in $\mathrm{MC}$ dendritic tufts of neonatal rats and mice. We therefore exclude the possibility of an early interaction of cAMP and $\mathrm{Ca}^{2+}$-signaling pathways in the above-mentioned model for early odor preference learning.

\section{RESULTS}

We used olfactory slices prepared from both mouse and rat pups. Using both of these species, we took into account the fact that most behavioral work is done in rats, whereas the number of studies using genetic approaches in mice is increasing. Although data from different species were not pooled, no obvious differences were found in data between rats and mice. The morphology of postnatal development of rat MCs has been previously described (Malun and Brunjes 1996; Treloar et al. 1999). In agreement with these studies, dye-filled mouse MCs between postnatal day 5 (P5) and P8 exhibit a distal dendritic tuft less developed than that in adults, and occasionally also exhibit a secondary apical dendrite. Figure 1 shows a dye-filled P6 mouse MC with a single apical dendrite along with a schematic drawing indicating the patch-clamp electrode and placement of the stimulation electrode on the ON. A single electrical stimulus to the $\mathrm{ON}$ induced an excitatory postsynaptic potential (EPSP) recorded at the soma of MCs. The EPSP gradually increased in amplitude with increasing stimulus intensity and eventually reached threshold for triggering action potentials (Fig. 2A). Calcium imaging revealed that both suband supra-threshold EPSPs were associated
A

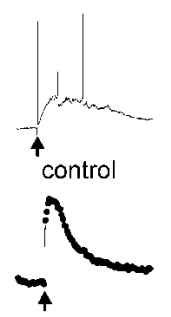

A

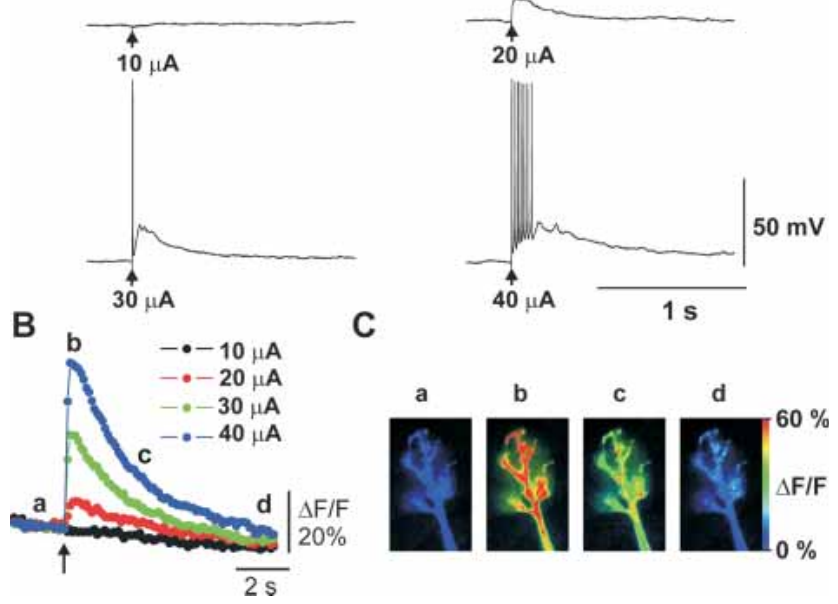

Figure 2 Olfactory nerve (ON) stimulation-induced electrical and $\mathrm{Ca}^{2+}$ signaling. (A) Sub- and supra-threshold excitatory postsynaptic potentials (EPSPs) were evoked by single stimulation pulses (arrows) to the $\mathrm{ON}$ at varying intensities and recorded from the soma of MCs. (B) Time course of $\mathrm{Ca}^{2+}$ signals in a tufted dendritic terminal recorded simultaneously with electrical signals shown in $A$. (C) Map of increase in $\left[\mathrm{Ca}^{2+}\right]_{i}$ measured at time points indicated in $B$.

with a transient rise in $\left[\mathrm{Ca}^{2+}\right]_{\mathrm{i}}$ in the tufted dendritic terminal (Fig. 2B,C). Maps of these $\mathrm{Ca}^{2+}$ signals indicated that the amplitude of $\mathrm{Ca}^{2+}$ transients was relatively homogenous over the whole tuft, but slightly smaller in the adjacent apical dendrite segment (Fig. 2C).

The $\mathrm{Ca}^{2+}$ transients associated with synaptic transmission between $\mathrm{ON}$ and MCs may be caused by $\mathrm{Ca}^{2+}$ influx through NMDA receptors or by activation of voltage-gated calcium channels (VGCCs). To investigate these possibilities, we applied the NMDA receptor antagonist D-APV, which reduced, but did not abolish, the EPSPs and associated calcium transients $(n=7$, $P<0.005$, Fig. 3). Both signals were abolished with the additional application of an AMPA receptor blocker, NBQX (data not shown), indicating that, in the absence of NMDA receptor activation, activation of AMPA receptors suffices to produce a $\mathrm{Ca}^{2+}$ elevation via activation of VGCCs. The effect of D-APV demonstrates a significant contribution of NMDA receptors to the compound EPSP. The reduction of the $\mathrm{Ca}^{2+}$ signal by D-APV could be accounted for by the reduced postsynaptic depolarization (see Fig. 1). The close correlation between the amplitudes of postsynaptic membrane depolarization and $\mathrm{Ca}^{2+}$ signals (Fig. 1) suggests

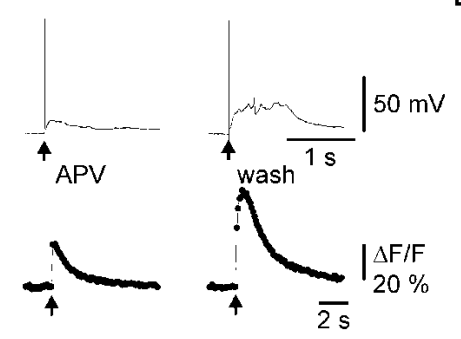

B

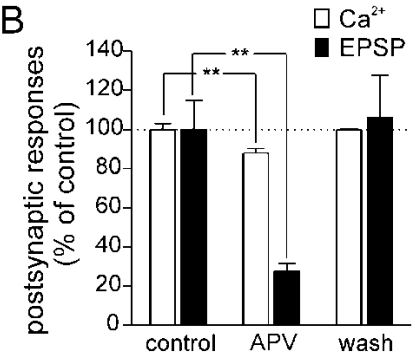

Figure 3 Effect of NMDA receptor blockade on ON stimulation-induced glomerular $\mathrm{Ca}^{2+}$ signals. (A) Postsynaptic electrical (top traces) and $\mathrm{Ca}^{2+}$ signals (bottom traces) in control ACSF, in the presence of D-APV $(50 \mu \mathrm{M})$, and after washout of D-APV. Arrows indicate times of ON stimulations. Note that D-APV reduced both $\mathrm{Ca}^{2+}$ signal and EPSPs. (B) Statistical analysis of experiments illustrated in $A . \mathrm{Ca}^{2+}$ signals and EPSPs were normalized to the responses obtained in control ACSF and expressed as the mean \pm SEM $(n=7)$. Asterisks indicate statistical significant difference as compared with control $(P<0.005)$. 
that the bulk of $\mathrm{Ca}^{2+}$ influx associated with the EPSP is mediated by VGCCs. However, we cannot exclude the possibility that a component of the $\mathrm{Ca}^{2+}$ transients was caused by flux through NMDA receptors or calcium released from intracellular sources.

We then studied the effects of $\beta$-adrenoceptor agonists and antagonist on ON stimulation-induced glomerular responses in neonatal rats (Fig. 4). Three drugs were used as follows: isoproterenol $(1-10 \mu \mathrm{M}$, a standard selective $\beta$-adrenoceptor agonist, $n=4)$, xamoterol ( $1 \mu \mathrm{M}$, a partial $\beta_{1}$-adrenoceptor agonist, $\left.n=2\right)$ and betaxolol $\left(1 \mu \mathrm{M}\right.$, a selective $\beta_{1}$-adrenoceptor antagonist, $n=4)$. None of the above drugs exerted significant effects on the ON-MC EPSPs or on the associated $\mathrm{Ca}^{2+}$ signals. We confirmed these results in olfactory slices from neonatal mice by testing the effect of isoproterenol on ON stimulation-induced glomerular responses either sub- or supra-threshold for action potential induction. Isoproterenol did not affect the electrical or the $\mathrm{Ca}^{2+}$ signaling in MCs in either condition (Fig. 5).

Our results were surprising, as previous work conducted in other laboratories suggested that L-type calcium channels are present in MCs (Trombley 1992; Tanaka et al. 1995; Wang et al. 1996; Davila et al. 2003), and it is generally assumed that these channels are modulated by $\beta$-adrenoceptor activation in other cortical structures (Gray and Johnston 1987; Huang et al. 1993). Because at least $\beta_{1}$-adrenoceptor are expressed in MCs (Yuan et al. 2003), we reinvestigated the expression of $\mathrm{Ca}^{2+}$ channel subtypes in MCs using immunocytochemical and pharmacological measures. Immunocytochemistry revealed clear immunoreactivity with antibodies against $\alpha 1 \mathrm{~A}$ (Cav2.1, P/Q-type) and $\alpha 1 \mathrm{~B}$ (Cav2.2, N-type), but not against L-type $\alpha 1 \mathrm{C}$ (Cav1.2)/ $\alpha 1 \mathrm{D}$ (Cav1.3) $\mathrm{Ca}^{2+}$ channel subunits in MCs and their tufted dendrites (Fig. 6). Whereas $\alpha 1 \mathrm{~A}$ and $\alpha 1 \mathrm{~B}$ antibodies clearly labeled $\mathrm{MC}$ soma and glomeruli (also granule cell soma for $\alpha 1 \mathrm{~B}$; Fig. $6 \mathrm{~A}, \mathrm{~B})$, no obvious staining was observed in mitral cell soma and glomeruli by L-type VGCC subunit $\alpha 1 \mathrm{C}$ antibody (Fig. 6C). $\alpha 1 \mathrm{D}$ immunocytochemistry revealed very weak immunoreactivity throughout the MOB (Fig. 6D). The external and internal plexiform layers, however, were heavily stained by the $\alpha 1 \mathrm{C}$ antibody, suggesting that granule cell dendrites (or MC lateral dendrites, see Discussion) express L-type $\alpha 1 C$ subunits of VGCCs. The lack of immunoreactivity for $\alpha 1 \mathrm{C}$ (Cav1.2) and $\alpha 1 \mathrm{D}$ (Cav1.3) subunits suggest that L-type $\mathrm{Ca}^{2+}$ channels are absent or poorly expressed in the cell body and apical dendrites of MCs. To inves-
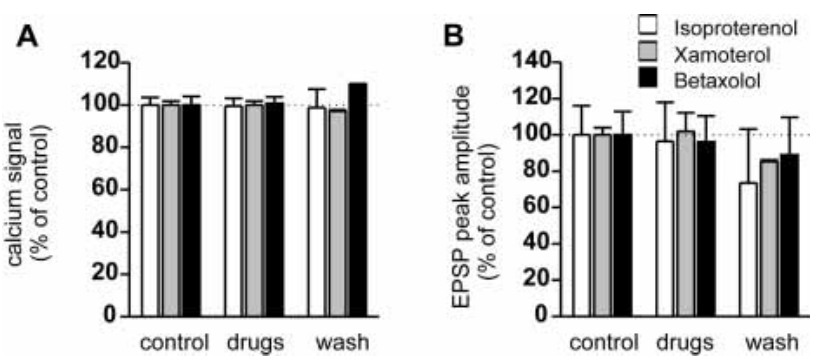

Figure 4 The effects of $\beta$-adrenoceptor agonists and antagonist on ON stimulation-induced glomerular responses in neonatal rats. $(A)$ Effects of $\beta$-adrenoceptor agonists and antagonist on glomerular $\mathrm{Ca}^{2+}$ signaling. (B) Effects of $\beta$-adrenoceptor agonists and antagonist on EPSPs. $\mathrm{Ca}^{2+}$ signals of the tufted dendritic terminals and membrane potentials were recorded simultaneously. Note that application of $\beta$-adrenoceptor ligands exhibited no significant effect on either the $\mathrm{Ca}^{2+}$ signal or the EPSPs. $\mathrm{Ca}^{2+}$ signals and EPSPs were normalized to the responses obtained in control ACSF and expressed as the mean \pm SEM. Isoproterenol (1-10 $\mu \mathrm{M}, n=4)$, standard $\beta$-adrenoceptor agonist; xamoterol $(1 \mu \mathrm{M}, n=2)$, $\beta_{1}$-adrenoceptor partial agonist; betaxolol $(1 \mu \mathrm{M}, n=4)$, selective $\beta_{1^{-}}$adrenoceptor antagonist.
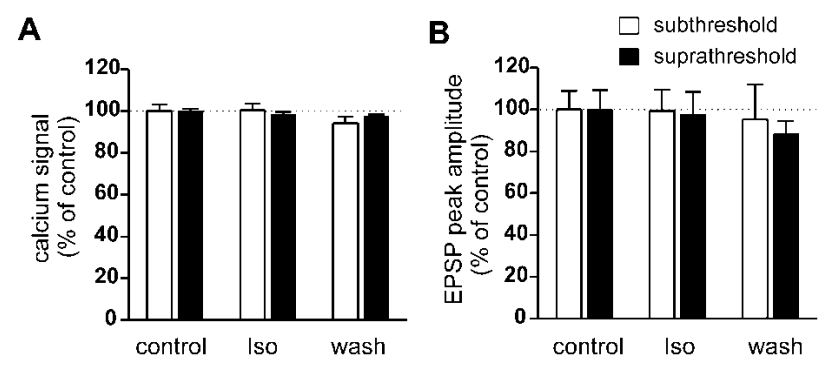

Figure 5 The effects of isoproterenol on ON stimulation induced glomerular responses in neonatal mice. (A) Effects of isoproterenol (1-10 $\mu \mathrm{M})$ on glomerular $\mathrm{Ca}^{2+}$ signals. Responses to sub- and supra-threshold stimulations (i.e., with and without action potential) are shown separately. (B) Effects of isoproterenol on EPSPs with and without action potentials. $\mathrm{Ca}^{2+}$ signals of the glomeruli and membrane potentials were recorded simultaneously. Note that isoproterenol exhibited no significant effect on either the $\mathrm{Ca}^{2+}$ signal or the EPSPs. $\mathrm{Ca}^{2+}$ signals and EPSPs were normalized to the responses obtained in control ACSF and expressed as the mean $\pm \operatorname{SEM}(n=14$ and $n=5$ for sub- and supra-threshold stimulations, respectively).

tigate this issue further, we tested the effect of nimodipine (an L-type $\mathrm{Ca}^{2+}$ channel blocker) on electrical and $\mathrm{Ca}^{2+}$ signaling mediated by ON-MC synapses. Nimodipine $(10 \mu \mathrm{M})$ had no significant effect on either the ON-MC EPSPs or the associated $\mathrm{Ca}^{2+}$ signals (Fig. 7A,B). Nimodipine also did not affect field EPSPs induced by $\mathrm{ON}$ stimulation recorded in the glomerular layer (Fig. 7C,D).

\section{DISCUSSION}

Given the critical role of $\beta$-adrenoceptor activation in early odor preference learning, it is surprising that the physiological mechanisms associated with $\beta$-adrenoceptor activation in MCs of the MOB have not been elucidated in detail. The present study revealed that $\beta$-adrenoceptor activation interferes $\alpha \mathbf{A}$
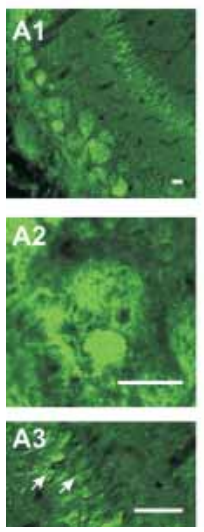

$\alpha 1 B$
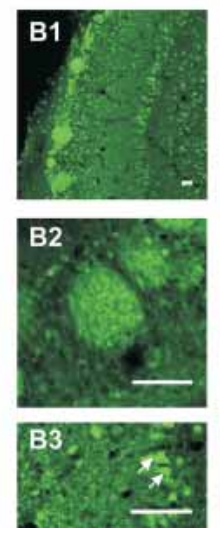

$\alpha 1 C$
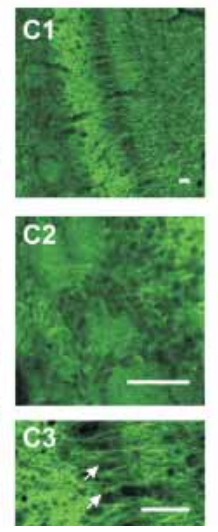

$\alpha 1 D$

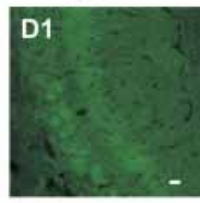

D2

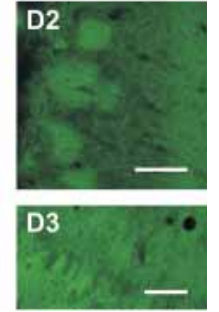

Figure 6 Immunocytochemical locations of VGCC subunits in neonatal rat $(\mathrm{P} 7, n=6)$ olfactory bulbs. Panels 1 through 4 indicate the immunoreactivity with antibodies against $\alpha 1 \mathrm{~A}(\mathrm{P} / \mathrm{Q}$ type; $6 \mathrm{~A}), \alpha 1 \mathrm{~B}(\mathrm{~N}$-type; $6 \mathrm{~B})$, $\alpha 1 \mathrm{C}$ (L-type; 6C) and $\alpha 1 \mathrm{D}$ (L-type; 6D) distinctively. $\alpha 1 \mathrm{~A}$ subunit was located mainly in the glomeruli $(A 1,20 \times ; A 2,60 \times)$ and mitral cell soma $(A 3,60 \times) . \alpha 1 B$ subunit antibody stained strongly all major neurons including mitral cells, granule cells (B1, 20×; B3, 60×), periglomerular cells $(B 1 ; B 2,60 \times)$ and also glomeruli (B1, B2). On the contrary, $\alpha 1 C$ antibody stained heavily in the EPL and IPL $(C 1,20 \times ; C 3,60 \times)$. However, mitral cell and granule cell soma (C1 and C3), and glomeruli (C1 and $C 2,60 \times$ ) exhibited no immunoreactivity. $\alpha 1 \mathrm{D}$ antibody did not produce any specific staining in the OB (D1, 20×; D2 and D3, 60×).

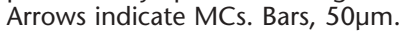


A
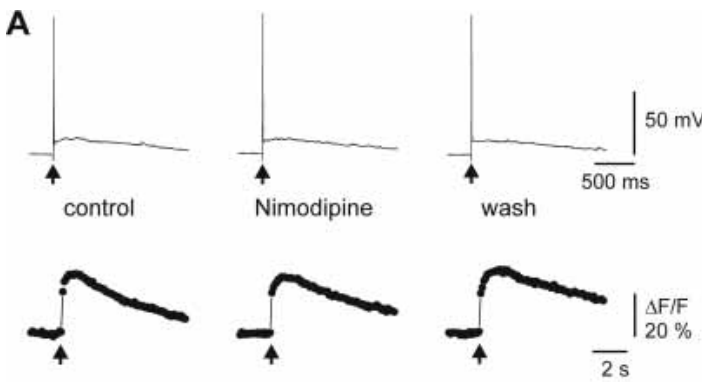

C

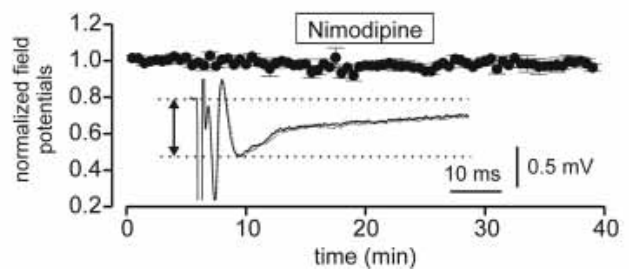

Figure 7 The effects of nimodipine, a blocker of L-type voltage-gated calcium channels, on synaptic transmission at $\mathrm{ON}-\mathrm{MC}$ synapses. $(A)$ Electrical and calcium signaling at $\mathrm{ON}-\mathrm{MC}$ synapses before, during, and after application of nimodipine $(10 \mu \mathrm{M})$ to the bath solution. $(B)$ summary data (mean \pm SEM, $n=4$ ) obtained as illustrated in $A$. Note that nimodipine exhibited no significant effect on either the $\mathrm{Ca}^{2+}$ signal or the EPSPs. $\mathrm{Ca}^{2+}$ signals, and EPSPs were normalized to the responses obtained in control ACSF and expressed as the mean \pm SEM. (C) Effect of nimodipine $(10 \mu \mathrm{M})$ on the field EPSPs evoked by ON stimulation and recorded in glomeruli. (Inset) Field EPSPs before (dotted line) and during (solid line) application of nimodipine. Horizontal lines demark the amplitude of the field EPSP. (D) Summary data (mean \pm SEM, $n=5$ ) obtained as illustrated in C. NPD, nimodipine.

neither with synaptic transmission between ON and MCs nor with $\mathrm{Ca}^{2+}$ signaling in the distally tufted apical dendrites of MCs.

\section{Involvement of Adrenoceptors in Early Odor Preference Learning}

In an early hypothesis accounting for the role of noradrenergic mechanisms in early odor preference learning, Wilson and Sullivan (1994) proposed that NE may act on granule cells to disinhibit MCs and modify the synaptic efficacy between the MCs and granule cells. Other studies suggested that the disinhibitory effect of NE on MCs is mediated through $\alpha$-adrenoceptors (Trombley 1992, 1994; Trombley and Shepherd 1992; Jiang et al. 1996). More recently, Yuan et al. (2003) proposed that NE via $\beta_{1^{-}}$ adrenoceptors mediates the production of cAMP, which facilitates $\mathrm{Ca}^{2+}$-dependent phosphorylation of CREB in MCs. Following CRE-regulated gene expression, odor-encoding MCs may increase their excitability for the learned odor (Yuan et al. 2002, 2003). The increased excitability was proposed to result from a change in the synaptic efficacy between the ON input and the MCs (Sullivan and Wilson 2003; Yuan et al. 2003). Consistent with this model, isoproterenol ( $\beta$-adrenoceptor agonist) induced increases in the excitability of MCs have been reported (Wilson and Leon 1988; Yuan et al. 2000; Hayar et al. 2001). It was hypothesized that isoproterenol may increase $\mathrm{Ca}^{2+}$ currents in the dendrites of mitral or tufted cells (Hayar et al. 2001), a mechanism that has been established in the hippocampus (Katsuki et al. 1997) and the amgydala (Huang et al. 1993, 1996).

\section{$\beta$-Adrenoceptor Activity, Electrical and Calcium Signaling at ON-MC Synapses}

Our data demonstrated that $\beta$-adrenoceptor activation did not affect EPSPs recorded from MCs by ON stimulation, which is tufts of MCs. To test the above possibili-

with a previous study (Haya et al. 2001). Furthermore, $\beta$-adrenoceptor activation did not affect $\mathrm{Ca}^{2+}$ signals induced by $\mathrm{ON}$ stimulation and recorded in MC apical dendrites. There are no previous studies that have tested the effect of $\beta$-adrenoceptor activation on $\mathrm{Ca}^{2+}$ signaling in MCs in slices. Previous work by Trombley $(1992,1994)$ on cultured olfactory neurons suggested that NE inhibits synaptic transmission from MCs to granule cells by reducing $\mathrm{Ca}^{2+}$ currents via $\alpha$-adrenoceptors. Our working hypothesis - that $\beta$-adrenoceptor activation may modulate $\mathrm{Ca}^{2}$ signaling in MC dendrites-was motivated by findings reported in other systems, in which the up-regulation of $\mathrm{Ca}^{2+}$ signals through L-type VGCCs by $\beta$-adrenoceptor activation is involved in learning and memory (Huang et al. 1993, 1996; Bauer et al. 2002). The lack of $\beta$-adrenergic modulation of $\mathrm{Ca}^{2+}$ signals in the mitral cell apical dendrite may be explained by three possibilities as follows: (1) $\beta$-adrenoceptors do not colocalize with L-type VGCCs, (2) $\beta$-adrenoceptors colocalize with L-type VGCCs, but do not interact with them, or (3), L-type calcium channels are absent in the apical dendritic ties, we performed immunocytochemical and pharmacological experiments to locate VGCCs, especially L-type VGCCs, in the olfactory bulb, and to test their role in the ON stimulationinduced $\mathrm{Ca}^{2+}$ changes.

In contrast to P/Q $(\alpha 1 \mathrm{~A})$ and $\mathrm{N}(\alpha 1 \mathrm{~B})$ subunits, which were densely stained in MC soma and glomeruli, the L-type ( $\alpha 1 \mathrm{C}$ and $\alpha 1 D)$ antibody did not stain either of these structures. The lack of immunoreactivity for L-type calcium subunits in MC soma and glomeruli, in which the MC sends its apical dendrite, may explain the lack of effect of $\beta$-adrenoceptor activation on $\mathrm{Ca}^{2+}$ signaling in MC tufted dendrites in glomeruli. To support the immunocytochemical evidence, we tested the effect of nimodipine (an L-type VGCC blocker) on electrical signaling induced by ONMC synapses. Nimodipine had no significant effect on either the EPSPs or the associated calcium signals. Whereas these electrophysiological data do not exclude the possibility of an involvement of L-type calcium channel in activities of MCs that were not tested in the present study, they confirm the lack of involvement of L-type VGCCs in the $\mathrm{Ca}^{2+}$ signaling in MCs during ON stimulation. The immunoreactivity for $\alpha 1 \mathrm{C}$ subunits of VGCCs in the external plexiform layer may indicate the presence of $\mathrm{L}$ type VGCCs in MC lateral dendrites. Preliminary experiments ( $n=3$ cells; data not shown) revealed, however, that nimodipine also had no effect on $\mathrm{Ca}^{2+}$ transients induced in lateral dendrites by back-propagating action potentials that were induced through depolarization of the cell body. These results are consistent with two previous studies showing little effect of an L-type $\mathrm{Ca}^{2+}$ channel blocker, nifedipine, on either mitral cell self-excitation (Friedman and Strowbridge 2000) or lateral dendrodendritic inhibition (Isaacson and Strowbridge 1998).

In summary, our results exclude the role of $\beta$-adrenoceptor activation in directly regulating $\mathrm{Ca}^{2+}$ signals in MCs induced by the ON stimulation. Thus, our results suggest that the cAMP-UCS and $\mathrm{Ca}^{2+}-\mathrm{CS}$ pathways may converge solely at the stage of CREB phosphorylation in early odor preference learning. 


\section{MATERIALS AND METHODS}

\section{Slice Preparation}

Experiments were performed on slices obtained from SpragueDawley rats and ICR mouse pups of both sexes aged between P5 and P8. Briefly, animals were anesthetized in ice and decapitated. The brain with the two olfactory bulbs was removed and glued to the stage of a Vibroslicer (VT 1000S, Leica). The brain was positioned so that the bulbs were in approximately the same horizontal plane with the most basal part of the brain. Slices (250$300-\mu \mathrm{m}$ thick) were cut and allowed to recover at $32^{\circ} \mathrm{C}$ for $1 \mathrm{~h}$, and then at room temperature for up to $8 \mathrm{~h}$. After at least $1 \mathrm{~h}$ of incubation, slices were transferred into a recording chamber and were perfused with artificial cerebrospinal fluid (ACSF; composition in mM: $\mathrm{NaCl} 118, \mathrm{NaHCO}_{3} 25, \mathrm{NaH}_{2} \mathrm{PO} 41, \mathrm{KCl} 3, \mathrm{MgCl}_{2} 1$, $\mathrm{CaCl}_{2} 2$, and glucose 10). For electrophysiological and fluorescence recordings, slices were placed in an immersion-type perfusion chamber mounted on the stage of an upright microscope (Axioskope 2, Carl Zeiss) and visualized using a $40 \times$ waterimmersion lens.

\section{Electrophysiology}

Patch-clamp experiments were performed in whole-cell configuration. Patch electrodes (3.5-4.5 $\mathrm{M} \Omega$ resistance) were pulled from borosilicate glass using a two-stage vertical puller (PP-810, Narishige) and contained (in millimolars) $\mathrm{KCl} \mathrm{9,} \mathrm{KOH} \mathrm{10,} \mathrm{K-}$ gluconate $120, \mathrm{MgCl}_{2} 3.48, \mathrm{NaCl} 4$, HEPES 10, sucrose 17.5, $\mathrm{Na}_{2}$ ATP 4, $\mathrm{Na}_{3}$ GTP 0.4, and 0.1 Oregon Green 488 BAPTA-1; ( $\mathrm{pH}$ 7.25) osmolarity $300 \mathrm{mOsm}$. Extracellular field recordings were recorded with a glass pipette (filled with ACSF, 1.0-2.0 M $\Omega$ ) pulled from borosilicate glass and placed in the center of a glomerulus. Glass pipettes $(0.8-1.5 \mathrm{M} \Omega$ ) pulled from borosilicate glass and filled with ACSF were used for electrical stimulation (negative current pulse, 5-100 $\mu \mathrm{A}, 300 \mu$ s).

\section{Imaging}

Fluorescence of Oregon Green was excited by epi-illumination $(488 \mathrm{~nm})$ with light provided by a monochromator, and detected by a cooled 12-bit charge coupled device (CCD) under the control of Till Vision software (Till Photonics). A filter set consisting of a dichroic beam splitter (DCLP 505 LP) and an emission filter $(535 \pm 25 \mathrm{~nm})$ was used. Fluorescence from intracellularly loaded dye equilibrated throughout the cell within 30-40 min of commencing whole-cell configuration. Changes of $\left[\mathrm{Ca}^{2+}\right]_{\mathrm{i}}$ were expressed as relative fluorescence changes $(\Delta \mathrm{F} / \mathrm{F}$, where $\mathrm{F}$ is the fluorescence before stimulus and $\Delta \mathrm{F}$ is the evoked change in fluorescence). For traces showing the time course of $\Delta \mathrm{F} / \mathrm{F}$, fluorescence was measured as the integral over the entire tufted dendrite. Color-coded maps of $\Delta \mathrm{F} / \mathrm{F}$ were obtained using custommade macros under Image-Pro Plus (Media Cybernetics). $\Delta \mathrm{F} / \mathrm{F}$ image values were unreliable in regions where the absolute baseline fluorescence level $(F)$ approached zero (i.e., at the border of the dye filled cell) and $\Delta \mathrm{F} / \mathrm{F}$ values were undefined when $F$ reaches zero. Therefore, a masking technique was used, in which the brightness of each pixel of the $\Delta \mathrm{F} / \mathrm{F}$ maps was derived from the corresponding $F$ value. As a result, regions exhibiting no dye fluorescence $(F=0)$ are black, and dim structures, such as very fine processes, are in darkened colors.

\section{Statistics}

Summary data are expressed as mean \pm SEM; and $n$ represents the number of experiments performed on different MCs. Significance was determined using Student's unpaired $t$ test, unless stated otherwise.

\section{Immunocytochemistry}

P7 rats and mice were anesthetized with an overdose of pentobarbital sodium and perfused transcardially with ice-cold saline, followed by $4 \%$ paraformaldehyde in $0.1 \mathrm{M} \mathrm{PB}(\mathrm{pH}$ 7.4) for 30 min. Brains were removed and post-fixed in the same fixative for $1 \mathrm{~h}$, then transferred to $30 \%$ sucrose solution overnight. The olfactory bulbs were sectioned with a cryostat at $30 \mu \mathrm{m}$. Olfactory bulb sections were either collected free-floatingly, or mounted onto subbed slide glass. After incubation with $10 \%$ normal goat serum for $30 \mathrm{~min}$ at room temperature, sections were incubated overnight in one of the following antibodies: $\alpha 1 \mathrm{~A}$ (P/Q-type), $\alpha 1 \mathrm{~B}$ (N-type), $\alpha 1 \mathrm{C}$, and $\alpha 1 \mathrm{D}$ (L-type) (diluted 1:200, Chemicon), in PBS containing $0.3 \%$ Triton X-100 and $2 \%$ normal goat serum. After washing with PBS, sections were incubated with a secondary antibody (Alexa488, diluted 1:1000, Molecular Probes). Immunoreactions were observed under a confocal microscope (Olympus Fluoview). To establish the specificity of the immunostaining, a negative control test (incubation without primary antibody) or a preabsorption test was performed. All labeling interpreted as specific immunoreactivity was absent in these controls.

\section{ACKNOWLEDGMENTS}

We thank Jennifer Slemmer for careful reading and comments. This work was supported by an intramural grant of the RIKEN Brain Science Institute.

The publication costs of this article were defrayed in part by payment of page charges. This article must therefore be hereby marked "advertisement" in accordance with 18 USC section 1734 solely to indicate this fact.

\section{REFERENCES}

Bauer, E.P., Schafe, G.E., and LeDoux, J.E. 2002. NMDA receptors and L-type voltage-gated calcium channels contribute to long-term potentiation and different components of fear memory formation in the lateral amygdala. J. Neurosci. 22: 5239-5249.

Coopersmith, R. and Leon, M. 1995. Olfactory bulb glycogen metabolism: Noradrenergic modulation in the young rat. Brain Res. 647: 230-237.

Davila, N.G., Blakemore, L.J., and Trombley, P.Q. 2003. Dopamine modulates synaptic transmission between rat olfactory bulb neurons in culture. J. Neurophysiol. 90: 395-404.

Day, H.E., Campeau, S., Watson Jr., S.J., and Akil, H. 1997. Distribution of $\alpha 1 \mathrm{a}-, \alpha 1 \mathrm{~b}$ - and $\alpha 1 \mathrm{~d}$ - adrenergic receptor mRNA in the rat brain and spinal cord. J. Chem. Neuroanat. 13: 115-139.

Friedman, D. and Strowbridge, B.W. 2000. Functional role of NMDA autoreceptors in olfactory mitral cells. I. Neurophysiol. 84: 39-50.

Gray, R. and Johnston, D. 1987. Noradrenaline and $\beta$-adrenoceptor agonists increase activity of voltage-dependent calcium channels in hippocampal neurons. Nature 327: 620-622.

Hardingham, G.E., Arnold, F.J., and Bading, H. 2001. Nuclear calcium signaling controls CREB-mediated gene expression triggered by synaptic activity. Nat. Neurosci. 4: 261-267.

Hayar, A., Heyward, P.M., Heinbockel, T., Shipley, M.T., and Ennis, M. 2001. Direct excitation of mitral cells via activation of $\alpha 1$-noradrenergic receptors in rat olfactory bulb slices. $J$. Neurophysiol. 86: 2173-2182.

Huang, C.C., Tsai, J.J., and Gean, P.W. 1993. Enhancement of NMDA receptor-mediated synaptic potential by isoproterenol is blocked by Rp-adenosine 3',5'-cyclic monophosphothioate. Neurosci. Lett. 161: $207-210$.

Huang, C.C., Hsu, K.S., and Gean, P.W. 1996. Isoproterenol potentiates synaptic transmission primarily by enhancing presynaptic calcium influx via P- and/or Q-type calcium channels in the rat amygdala. I. Neurosci. 16: 1026-1033.

Isaacson, J.S. and Strowbridge, B.W. 1998. Olfactory reciprocal synapses: Dendritic signaling in the CNS. Neuron 20: 749-761.

Jiang, M., Griff, E.R., Ennis, M., Zimmer, L.A., and Shipley, M.T. 1996. Activation of locus coeruleus enhances the responses of olfactory bulb mitral cells to weak olfactory nerve input. J. Neurosci. 16: 6319-6329.

Katsuki, H., Izumi, Y. and Zorumski, C.F. 1997. Noradrenergic regulation of synaptic plasticity in the hippocampal CA1 region. J. Neurophysiol. 77: 3013-3020.

Malun, D. and Brunjes, P.C. 1996. Development of olfactory glomeruli: Temporal and spatial interactions between olfactory receptor axons and mitral cells in opossums and rats. J. Comp. Neurol. 368: 1-16.

McLean, J.H. and Shipley, M.T. 1991. Postnatal development of the noradrenergic projection from locus coeruleus to the olfactory bulb in the rat. J. Comp. Neurol. 304: 467-477.

McLean, J.H., Shipley, M.T., Nickell, W.T., Aston-Jones, G., and Reyher, C.K. 1989. Chemoanatomical organization of the noradrenergic input from locus coeruleus to the olfactory bulb of the adult rat. J. Comp. Neurol. 285: 339-349.

McLean, J.H., McCann, J., Darby-King, A., and Harley, C.W. 2003. Not 
only $\beta$ - but also $\alpha$-adrenoceptors are involved in early odor preference learning in the rat. ACHEMS $26^{\text {th }}$ annual meeting abstracts. P49.

Nicholas, A.P., Pieribone, V., and Hokfelt, T. 1993a. Distributions of mRNAs for $\alpha-2$ adrenergic receptor subtypes in rat brain: An in situ hybridization study. J. Comp. Neurol. 328: 575-594.

. 1993b. Cellular localization of messenger RNA for $\beta-1$ and $\beta-2$ adrenergic receptors in rat brain: An in situ hybridization study. Neuroscience 56: 1023-1039.

Shipley, M.T., Halloran, F.J., and de la Torre, J. 1985. Surprisingly rich projection from locus coeruleus to the olfactory bulb in the rat. Brain Res. 329: 294-299.

Sullivan, R.M. and Wilson, D.A. 1994. The locus coeruleus, norepinephrine, and memory in newborns. Brain Res Bull. 35: $467-472$.

. 2003. Molecular biology of early olfactory memory. Learn Mem. 10: $1-4$.

Sullivan, R.M., Wilson, D.A., and Leon, M. 1989. Norepinephrine and learning-induced plasticity in infant rat olfactory system. J. Neurosci. 9: 3998-4006.

Sullivan, R.M., Stackenwalt, G., Nasr, F., Lemon, C., and Wilson, D.A. 2000. Association of an odor with activation of olfactory bulb noradrenergic $\beta$-receptors or locus coeruleus stimulation is sufficient to produce learned approach responses to that odor in neonatal rats. Behav. Neurosci. 114: 957-962.

Tanaka, O., Sakagami, H., and Kondo, H. 1995. Localization of mRNAs of voltage-dependent $\mathrm{Ca}\left({ }^{2+}\right)$-channels: Four subtypes of $\alpha 1$ - and $\beta$-subunits in developing and mature rat brain. Brain Res. Mol. Brain Res. 30: 1-16.

Treloar, H.B., Purcell, A.L., and Greer, C.A. 1999. Glomerular formation in the developing rat olfactory bulb. J. Comp. Neurol. 413: 289-304.

Trombley, P.Q. 1992. Norepinephrine inhibits calcium currents and EPSPs via a G-protein-coupled mechanism in olfactory bulb neurons. J. Neurosci. 12: 3992-3998.

. 1994. Noradrenergic modulation of synaptic transmission between olfactory bulb neurons in culture: implications to olfactory learning. Brain Res. Bull. 35: 473-484.

Trombley, P.Q. and Shepherd, G.M. 1992. Noradrenergic inhibition of synaptic transmission between mitral and granule cells in mammalian olfactory bulb cultures. J. Neurosci. 12: 3985-3991.

Wanaka, A., Kiyama, H., Murakami, T., Matsumoto, M., Kamada, T., Malbon, C.C., and Tohyama, M. 1989. Immunocytochemical localization of $\beta$-adrenergic receptors in the rat brain. Brain Res. 485: $125-140$

Wang, X., McKenzie, J.S., and Kemm, R.E. 1996. Whole cell calcium currents in acutely isolated olfactory bulb output neurons of the rat. J. Neurophysiol. 75: 1138-1151.

Wilson, D.A. and Leon, M. 1988. Noradrenergic modulation of olfactory bulb excitability in the postnatal rat. Brain Res. 470: 69-75.

Wilson, D.A. and Sullivan, R.M. 1994. Neurobiology of associative learning in the neonate: Early olfactory learning. Behav. Neural. Biol. 61: $1-18$.

Winzer-Serhan, U.H., Raymon, H.K., Broide, R.S., Chen, Y., and Leslie, F.M. 1997. Expression of $\alpha 2$ adrenoceptors during rat brain development-I. $\alpha 2 \mathrm{~A}$ messenger RNA expression. Neuroscience 76: $241-260$.

Woo, C.C. and Leon, M. 1995. Distribution and development of $\beta$-adrenergic receptors in the rat olfactory bulb. J. Comp. Neurol. 352: $1-10$.

Yuan, Q., Harley, C.W., Bruce, J.C., Darby-King, A., and McLean, J.H. 2000. Isoproterenol increases CREB phosphorylation and olfactory nerve-evoked potentials in normal and 5-HT-depleted olfactory bulbs in rat pups only at doses that produce odor preference learning. Learn Mem. 7: 413-421.

Yuan, Q., Harley, C.W., McLean, J.H., and Knöpfel, T. 2002. Optical imaging of odor preference memory in the rat olfactory bulb. J. Neurophysiol. 87: 3156-3159.

Yuan, Q., Harley, C.W., and McLean, J.H. 2003. Mitral cell $\beta 1$ and 5-HT2A receptor colocalization and cAMP coregulation: A new model of norepinephrine-induced learning in the olfactory bulb. Learn Mem. 10: 5-15.

Received February 6, 2004; accepted in revised form June 3, 2004. 


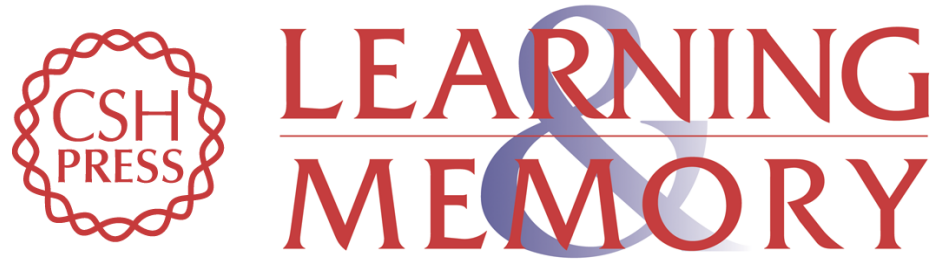

Calcium Signaling in Mitral Cell Dendrites of Olfactory Bulbs of Neonatal Rats and Mice During Olfactory Nerve Stimulation and $\beta$ -Adrenoceptor Activation

Qi Yuan, Hiroki Mutoh, Franck Debarbieux, et al.

Learn. Mem. 2004, 11:

Access the most recent version at doi:10.1101//m.75204

References This article cites 37 articles, 9 of which can be accessed free at: http://learnmem.cshlp.org/content/11/4/406.full.html\#ref-list-1

License

Email Alerting

Receive free email alerts when new articles cite this article - sign up in the box at the Service top right corner of the article or click here. 